\title{
Undifferentiated Carcinoma with Osteoclast-Like Giant Cells
}

National Cancer Institute

\section{Source}

National Cancer Institute. Undifferentiated Carcinoma with Osteoclast-Like Giant Cells. NCI Thesaurus. Code C63622.

A usually agg ressive malignant epithelial neoplasm composed of atypical cells which do not display evidence of glandular or squamous differentiation and giant cells resembling osteoclasts. 